Youn, Hee-kyung

University of Pretoria

\title{
A discussion about difficulties of university education for Korean missionary children
}

\begin{abstract}
In this article, "a discussion about university education for Korean missionary children", the researcher describes the purpose of education for Korean missionary children and their issues of university entrance. The most significant problem encountered by Korean missionary children is identity. Regarding this, the Korea World Missions Association (KWMA) defined the purpose of education for Korean missionary children to be citizens of God, citizens of the world, and citizens of Korea. Since the definition was proclaimed, mission agencies and missionaries in Korea stimulate Korean missionary children to enter university in Korea, in terms of establishing these identities. Since Korea expended special admission allowances for university entrance in 1997 to missionary children, a tendency has arisen that Korean missionary children changed from a Western to a Korean college/ university (Back 2007:1). However, the system of special admission allowance has recently been complicated and this system may be more stringent in future. This new attitude towards the special admission allowance for university entrance will influence Korean missionary children in future. Hence, Korean missionary parents and mission agencies need to be open minded instead of persisting in preconceived ideas concerning university education. Personal character and preference of college/ university options must be seriously considered, as they see the idea of 'one-sizefits' is not appropriate for all. Alternative options are needed to offer to Korean missionary children for their university education.
\end{abstract}

1. INTRODUCTION

In this study, the purpose of education for Korean missionary children and their issues of university entrance will be discussed.

According to Hale (2003:13), many mission agencies have discovered that the dilemma of the education of missionary children almost always tops the list of problems incurred on the mission field. A proper investigation established that the most important issue missionary parents are faced with concerns the educational needs of their children on the mission field. Directors of mission agencies find themselves faced with resignations and requests for reassignment, all too often due to this issue (Kim in Park 1999:55).

Due to the fact that the number of Korean missionary children has rapidly increased since 1980 , the need to reassess the educational requirements of Korean missionary children becomes imminent (Kwon 2006:4). Korean missionary parents experience more and more tension regarding their children's education. The most important issue Korean missionary parents are faced with, concerns the educational needs of their children on the field (Kim 1999:55). 


\subsection{The historical approach}

The history of Korean missionaries abroad is not a long one (Oh 2008:21). Korean missionaries, having little previous experience, often have difficulty in deciding how to raise their children. They also have difficulty to know the educational options available and which to choose. In general, before going to the mission field, many Korean missionaries are often unprepared to make decisions concerning how they will educate their children (Park 1999:35). According to Jung (1999:35), Korean missionary parents were often not serious about the educational system and options for their children. Rather, they send their children to MK/International schools without first considering the impact of these institutions on their children (Back 2007:2). There are various reasons ${ }^{1}$ Korean parents prefer to send their children to MK/International schools. However, Chan (1998:331) discovered that all MK/International schools are mainly based on the Western education system, are mostly English speaking and supported by Western teachers and staff. This causes several problems for the Korean missionary children regarding their education (Park 1999:35).

\subsection{The rapid increase of Korean missionary children}

"Since 1980 the missionary movement in Korea continues to grow faster than any other national missionary movement in the world" (Oh 2008:21). In 1979 there were 93 Korean missionaries abroad; by 2006 there were 14,905 Korean missionaries abroad ${ }^{2}$ and 174 mission agencies serving in 168 countries (Kim 2007.10.8). According to the Korea World Missions Association (KWMA), there were 16,616 Korean missionaries in 2007 (Cha 2007). This number is conservative, for it includes only missionaries belonging to mission agencies, not independent missionaries sent directly by a local church. Nor does it include workers who have committed themselves to missionary service for less than two years (Moon 2007). As the number of Korean missionaries rapidly increased from $1980^{3}$, the number of Korean missionary children naturally increased (Park 1999:34). Today, there are up to 12,000 Korean missionary children around the world (Jung 2008.8.13). Of these, approximately $60 \%$ are in schools on the mission fields and $40-50 \%$ are at MK/International schools (Back 2007:1).

As Korean missionary children grow older, and the number of them increases, parents experience more and more tension. Therefore, it is necessary to understand, support and assist missionary children in their educational endeavours (Park 1999:34). Korean missionary children at $\mathrm{MK} /$ International schools face problems concerning their education, such as differences in educational values, deriving from different social and cultural milieus, between the westernized educational school system and the Korean school system. Several problems tend to crop up, such

\footnotetext{
1 These schools have advantages such as academically high standards, excellent facilities and equipment, enrichment and specialized programs. One of the greatest advantages of these schools is the diversity of the backgrounds of the students. Children develop relationships with peers from many different nationalities. These friendships open the door to knowledge and understanding of a much larger worldview (Pollock \& Van Reken 2001:220-221).

2 There were approximately 5,000 Korean missionaries in 1999 (Korean MK Handbook 1999: 34), over 10,000 Korean missionaries in 2004 (Mission Journal 2004:31).

3 The turning point of the mission movement of the Korean church occurred during the 1980s (Oh 2008:43).
} 
as the cultural adjustment on the parts of both the international school and the student, due to poor preparation for Korean higher education (Kwon 2006:3). Moreover, these schools have the purposes to 'bring up excellent American citizens' and 'help adjust into the American society in a natural way after graduation of college/university in America' (Lee 2007). Furthermore, in the past most of the Korean missionary children went to America and other Western countries for university education, while their life in the Western countries shaped their identity and they became westernized. Because of this, Korean missionary children found it difficult to return and settle in Korea, and this affects their relationships with their parents and relatives (Jung 1999:32).

Therefore, in contrast to their attitude in the past, mission agencies and missionaries in Korea have become more serious to concern about how they can educate Korean missionary children in terms of the formulation of their identities (Park 1999:9). Korean missionary children have little sense of their own personal identity, because they experienced much cultural or national confusion, while they were growing up. They often struggle with the answering of questions like 'who they are', 'where they are going' and 'where do I fit or belong' (Park 1999:12-13).

It is very important that Korean missionary children establish their identities and understands who they are (Park 1999:92). With this knowledge they may have the power to adjust to Korea and other countries (Park 1992:93).

Thus, in 1993 KWMA defined the purpose of education for Korean missionary children to be citizens of God, citizens of the world, and citizens of Korea. Since the definition was proclaimed by mission agencies and missionaries in Korea, they have tried to help Korean missionary children to establish these identities. Unlike the past, Korean missionaries have to consider where their children will live permanently in the future before making a decision as to how to educate their children. Once this has been decided upon, parents need to make a correct long term plan with a balance between the reality and the ideal, their financial position, which citizenship their children will have, and the subsequent need for their future (Jung 1999:29). In deciding where their children will go for college/university, the preparation at high school level is of importance.

\section{4. CHILDREN}

\subsection{The social atmosphere of education in Korea and its influence upon Korean missionary families}

Most Korean missionary parents have high expectations for their children's education because the social demands concerning education takes high priority in the thinking of the Korean people. They consider a high standard of education to be the way to success in the life of their children. Thus, Korean parents put all their efforts into educating their children to send them to top universities. The social atmosphere in Korea also influences Korean missionary parents and thus they tend to follow this tendency for their children's education on the mission field. This causes Korean missionary families to use a lot of energy for their children's education on the mission field (Park 2002:38). However, they are not freed from this issue.

The social atmosphere concerning education in Korea will be discussed in 4.2 in order to understand a high fervour for children's education of Korean missionaries.

\subsection{The high fervour for children's education in Korea}

One of the hottest issues in Korea is the transition process from secondary education to higher education. High school students must undergo severe competition to gain entrance to prestigious colleges and universities. They believe that enrolment in a top-notch institution is their best chance to succeed in Korean society (Kim 2004:6). In Korea, most parents believe that 
educating their children is their most important responsibility. Because of this, they are willing to endure any amount of suffering in order to provide their children with an excellent education. Parents devote their time to helping their children and fully support them by finance. They put all their efforts into educating their children to send them to top universities (Weidman \& Park 2000). The social atmosphere in Korea also influences Korean missionary parents and thus they tend to follow this tendency for their children's education on the mission field. Hence, most of the Korean missionary parents have high expectations for their children's education as they expect children to have a good academic career after graduating from university. They place a great value on education, expect good marks, and force their children to study hard in order to enter top universities in America, Korea or any other country (Park 2002:38).

\subsection{Missionary children are a potential resource for the church}

According to Pollock (1998:31) and Lim (2004:9), missionary work and the education of missionary children are inseparable. Between $9 \%$ and $35 \%$ of missionaries attrition worldwide was related to issues involving their children, especially educational issues. Problems and tensions in schools attended by children of missionaries ${ }^{4}$ affect the entire mission community and the parents' work is influenced (Bowers 1998:31). In future, many mission fields will be situated amongst "Unreached People ${ }^{5}$ groups", without proper education facilities for missionary children. Thus, effective provision for the educational needs of missionary children is one of the key issues to be addressed before dispatching missionaries (Park 1999:56). The experience of missionaries' children abroad will enhance their potential ${ }^{6}$ in various ways (Bowers 1998:31). All educational enterprises worldwide are influenced by globalization and internationalization with worldwide perspectives developing. Pollock (1998:31) says that every country in the world has made at least some effort in this regard. Multilingualism is an asset in many cities of the world and there is a growing interest in developing the leadership potential of young adult missionary children, growing up in the "third culture" of an expatriate community (Park 1999:39). The solution of the situation missionary children face is part of the larger task of the church. Ward (1998:17) quotes Hill (1998:245) in saying that "missionary children are a potential resource" for the church. Hill emphasized that the mission needs internationalists who have grasped the larger vision of a world for God, and discovered that there is no group of people who has more potential of becoming internationalists than missionary children and third culture kids (Bowers 1998:244,245). In reality, Pollock and his co-workers (1998:31) discovered that 25\% of missionary children went back as missionaries, and $17 \%$ became career missionaries. Therefore mission agencies and churches need to care for missionary children with a view to their future impact on the world for the Lord (Bowers 1998:110).

\section{THE ISSUES OF UNIVERSITY EDUCATION FOR KOREAN MISSIONARY CHILDREN BECOME MORE CONSIDERABLE}

\subsection{College/university education in the Western countries}

Until the middle of the 1990s, many of the Korean missionary children lacked the ability to

4 Given prevailing conventions this study will refer to 'MK schools', rather than (but implying) schools attended by children of missionaries.

5 Unreached People is a group of people among which there is no indigenous community of believing Christians with adequate members and resources to evangelize them. http://www.joshuaproject.net/ definitions.hp\#unreached.

6 Eidse and Sichel (2004), Pollock and Van Reken (2001), and Bowers (1998) determined that missionary children have various advantages such as cultural exposure, ability to adapt and linguistic skills which is sought after in many cities in this world. 
speak the Korean language because they did not use it while they were at the MK/international schools on the mission field. The children had no opportunity to learn the Korean language at school, and were not motivated to study it by themselves while English was taught academically and used each day at school (Back 2007:1). As a result of the difficulty of the Korean language most of the Korean missionary children chose a college/university in America and other Western countries where English is spoken as a first language. Moreover, the different education system, the college entrance system and its admissions policy in Korea were other obstacles in terms of entering college/university in Korea. ${ }^{7}$ Korean missionary children who graduate from MK/ International schools on the mission field have advantages when entering college/university in America and/or in the Western countries. However, since the number of Korean missionary children rapidly increased (Kim 2007.10.8), and the number of college/university children has also increased (Jung 2008.8.13), the mission agencies and missionary parents in Korea have become more serious in their concerns about the problems that occurred at college/universities in the Western countries. For instance, they are: 1) the high cost of academic expense and boarding expense. Korean missionary parents face financial difficulties to support their children for university education in Western countries (Jae 2002:16). Recently it escalated with the stronger UK Pound and the US Dollar against the Korean Won. It affects the life of Korean missionary families and their ministry who have to use a large percentage of their available funds for their children's education (Back 2007:2), 2) the western culture shapes children's identities and they have become westernized and this causes tensions their relationship with their parents and family, 3) children have a lack of knowledge in the Korean language (Jung 1999:32). Because of this, Korean missionary children found it difficult to return and settle in Korea, and this affects their relationships with their parents and relatives. With this regard, the mission agencies and missionary parents in Korea stimulate Korean missionary children to enter college/university into Korea through the special admission allowance (Jae 2002:15).

\subsection{The contemporary tendency for university entrance}

Since Korea expended special admission allowances in $1997^{8}$ to missionary children, a tendency

7 The college entrance system and the college admissions policy in Korea has been affected considerably by social and political changes. Korean parents have an extreme desire for their children to receive higher education, especially from a prestigious college or university. Therefore, issues relating to college admissions policies easily attract public concern and this fact may explain why so many changes are constantly occurring in the college entrance process. Over the years, the Korean government has tended to increase its control over the student selection process. However, since the late 1980s, higher education institutions have recovered autonomy in selecting students. High schools have played an increasingly important role in this process because student records have been used as criterion for admission since 1981 (Kim, 2003b). At 110 colleges and universities, high school records account for $40 \% \sim 49 \%$ of the student selection process. High school records are important to entrance to colleges and universities.

8 Since 1997 special admission to universities in Korea has been available for the children of Korean embassies and Korean residents abroad. As the number of overseas Korean students are increasing, the object is to extend education at universities in Korea to educate Korean leaders as representatives overseas. 163 Universities (27 National universities and 136 Private universities) in Korea had admitted Korean overseas students in 2009 according the special admission requirements. Universities are allowed to select up to $10 \%$ of their subject courses and up to $2 \%$ of their entry students each year. Moreover, the universities have no number limit to select students who have completed the course of study in overseas for over 12 years. (Nho, C R 2002:9, pp.87-120)

There are two patterns of special admission. One is applied to children who complete the whole education system from primary to high school for 12 years. The other is applied to children who complete school for a certain number of years overseas. Each university has different rules for application for special admission. (The important recruitment outline for an overseas Korean and Foreigner, Korean Council for 
has arisen that missionary children changed from a Western to a Korean college/university (Back 2007:1). Many changes have occurred to the university entrance of Korean missionary children. Korean missionary children prefer to enter universities in Korea through the special admission (Jae 2002:15). Korean missionary parents were burdened financially with the support of their children's higher university education in western countries like America and Britain (Jae 2002:16). It became more difficult as worldwide economic depression increased; Korean missionary children had to consider university education in Korea instead of in a western country. On the other hand, since the purpose of education for Korean missionary children established by KWMA, Korean missionary parents promote their children to enter university in Korea regarding formulate their identities (Park 1999:9). For this missionary parents consider it an advantage for their children to gain a better understanding of Korean society and culture by studying at a Korean university (Back 2007).

\subsection{The special admission allowance}

The special admission allowance was originally established in 1977 for the children of a Foreign Service Officers in order to give them an opportunity to enter top college/university in Korea. However, this was expended its application in 1997 for Korean children abroad due to fact that many of them go abroad with their parents for immigrate, employment and study. Some of the reasons that Korea expended this application are as follows: 1) to give opportunities of getting university education in Korea for Korean nationals abroad, 2) to foster global leadership for them, 3) to strengthen their national consciousness as Koreans (Nho 2002:89). For these reasons, Korean missionary children have more opportunities to enter universities in Korea. Yet, it is considerable that this system is still changeable and the entering top universities in Korea are not easy for Korean missionary children. Nevertheless, the mission agencies and missionary parents in Korea stimulate university entrance into Korea for its advantages.

\section{THE ADVANTAGES AND DISADVANTAGES OF UNIVERSITY ENTRANCE INTO KOREA}

\subsection{Advantages}

\subsubsection{Establish identity}

Kim (1999:77) defines the meaning of self-identity as that which is formed by connecting the past, the present, the environment one lives in and what will happen in the future to identify oneself as a 'unique self'. According to Kim (1999:79) self-identification does not suddenly happen in one day. Rather, it is formulated by taking a fixed way of life and the requirements within one's environment into consideration. The process of identifying oneself is affected by a variety of knowledge and experiences such as those, which include both personal ones, together with that of the community. Some of these start from the moment of birth and are affected by the society's cultural, historical, economical and educational factors and the world becomes broader in this way. There are various factors playing various roles in the constitution of an identity and stated below are particular elements indicated by Kim (1999:79-83) that fulfil a very important role in the development of a personal identity: culture, history, society, language, and nationality.

Since KWMA (1993) defined the purpose of education for Korean missionary children as to be citizens of God, citizens of the world, and citizens of Korea, mission agencies and missionaries

University Education, 2008:132) 
in Korea have tried to help Korean missionary children to establish these identities through education. It is very important that Korean missionary children to understand who they are (Park 1999:92). With this knowledge they may have the power to adjust to Korea and other countries (Park 1992:93). This is essential for the purpose of re-entering Korea for further education and settling down to a new life.

\subsubsection{Obtain a degree of fluency in the Korean language}

Today there is a universal recognition of the importance of mother tongue education as well as of multilingualism. Languages are now regarded as an integral part of one's identity. This will have a greater impact on the education of missionary children in the globalized world (Ng 2007:1). According to Lloyd-Sidle and Lewis (2001:42), language is the basic tool of communication among people and is a very important symbol of identity for people, and mastering it is a sign of respect. They are able to obtain a degree of fluency in the Korean language while they trained at college/university in Korea.

\subsubsection{Understand Korean society and culture}

Besides language proficiency, they can have a close connection with the Korean culture and society while they trained at college/university in Korea (Park 1999:81,93,94). Cultural value may be realized and accomplished when a person enjoys the ideology, beliefs and value systems that are impressed in the culture (Park 1999:79). Thus, their life experiences at Korean universities will help them make wise choices when they want to settle in Korea in future.

\subsubsection{Building a close relationship with people in Korea}

Most of missionary children have no close relationships with their relatives in Korea while they are on the mission field, and they are able to develop close relationships with them during reentry. Furthermore, they can build close relationships with friends and other people in Korea. Building a good relationship with Korean people will be valuable for them in future.

\subsubsection{Preparation for military work for male children}

To take a military work of over two and a half years is an obligation for Korean men, and thus male missionary children need to concern this before they take this work. In many cases, missionary children struggle with the military work and face difficulties, as they have grown up in a different culture and society, and have language problems. Regarding this, experience Korean culture and society at university will help them to adjust better at the military.

\subsection{Disadvantages}

However, many problems have been raised in terms of entering university in Korea as below.

\subsubsection{Lack of information and of study materials for the preparation for university entrance in Korea}

Because of the situation on mission field, Korean missionary children in general have many difficulties to start at university. In many cases, it is difficult to collect sufficient and/or correct information about universities in Korea and in other countries, making preparation for entrance examinations not easy on the mission field. For instance, they need to take TOFUL ${ }^{9}$ and/or TOEIC ${ }^{10}$ tests when preparing for entering Korean universities and take SAT ${ }^{11}$ tests or other

9 TOFUL is a test of English as a foreign language.

10 TOEIC is a test of English for international communication.

11 Scholastic Aptitude Test (SAT) is required to apply college/university in North America. http://www. 
external examinations for universities in American and/or the other western countries. But to find materials for the tests and prepare for the exams is not easy on the mission field. There are institutes that give lessons for these exams in Korea, but it is difficult for Korean missionary children to take a chance for this study because of the expensive cost of lessons and airfare. Therefore, children need to prepare for the exams by themselves.

\subsubsection{A limited knowledge of the Korean language and of academic skills}

Children face many difficulties when they enter university in Korea with a limited knowledge of the Korean language, a different education system, and lack of academic skills. Children whose Korean is insufficient may suffer in their studies because the lectures are mostly offered in Korean. Some are able to take a specific course in English at the universities, but this is unusual. Thus, some of the Korean missionary children fail in the universities in Korea because of their lack of knowledge of the Korean language and of academic skills. In general, academic ability of missionary children is not good enough in comparison with the other students who had studied at high school in Korea. Hence, Korean parents need to consider their children's academic level and help them to prepare certain academic skills in terms of entering universities in Korea. Different education system also causes them (Jung 1999:29).

\subsubsection{The financial insufficiency and the separation from parents}

The academic and boarding expenses at universities should be a burden for Korean missionary families due to concern the high living cost in Korea. Most children are separated from their parents for university education in Korea and struggle with accommodation during school holidays because of the financial insufficiency. Therefore, they stay at relatives' houses and/or at other places and feel very tired in this situation. Recently, the mission agencies and the churches in Korea establish accommodations for re-entry children, but they are not enough. They also need their parents' support during the first year of college to help them settle (Pollock \& Van Reken 2001:188).

\subsubsection{Re-entry stresses}

In general, re-entry into Korea is hard for missionary children. Some fear leaving their host countries as they feel as if they are losing some important parts of them. This causes re-entry shock (Pollock \& Van Reken 2001:249). They also have cultural shock and feel as though they are strangers in their home country (2001:250). Children who have entered university in Korea and settled there are still in the minority and seem to be at risk in a strange land. In many cases children fell into despair through their cultural shock at the universities and with the Korean society. They realize that children at universities pursue very different goals from what they expect. They are often distressed with the environment at the universities and sometimes they leave universities because of many problems. They struggle with their incapacity to adapt to the Korean culture and separation from their parents (Seong 2006:191). On the other hand, they struggle with children at university who experience prejudice against them as they have entered university through special admission. Therefore, they need intensive care by their parents and/or people who they can trust (Nho 2002:114). However, it is culturally difficult for Korean missionaries going back to Korea to support their children during their time of re-entry to adjust to university education, due to the fact that most of the churches and mission agencies in Korea do not have a good understanding of the missionary children's need of their parents' support at re-entry (Park 1999:63).

Pollock and Van Reken (2001:241) say that good re-entry adjustment is not an event, but it

collegeboard.com 
is a process encompassing the life of the cross-cultural sojourner. The inputs of family, school and Christian community have structured the missionary children's perspective regarding God, as well as keys towards adjustment regarding him- or herself. If care is to be made available to all the missionary children, there must be a certain concentrated effort by parents and mission agencies to take initiative to prepare the way and encourage their children to take advantage of available services (2001:241).

Regarding this, mission agencies in Korea suggest some of the following guidelines towards helping missionary children at re-entry to the country of their new residence as below (Park 2007).

\subsection{Effective ways to help Korean missionary children with re-entry}

\subsubsection{The role of missionary parents}

- Help children to understand what they will be going through in the future. Parents need to discuss things about university education in Korea while their children are young for their understanding of their plans for the future.

- Help children develop positive self-esteems, strong faith in God, and emotional stability. Parents also need to consider their children's academic level and ability in the Korean language, and help them prepare certain skills for university education in Korea.

- Develop practical skills to adapt to the new home country's transport, currency, shopping, and geography.

- $\quad$ Take time to discuss certain information about the culture, social, political issues, mass media, sports and fashion of peer groups. Inform them and help them to get to know how to engage in proper relationships with elders, families and peers in Korea.

Pollock and Reken (2001: 254) also suggested that parents need to prepare some practical steps to help their children get through this process in a healthy rather than a harmful way. They emphasize, "it is the parents' responsibility to make sure their children are protected under their supervision" (2001:255).

\subsubsection{The role of the mission agencies and the churches in Korea}

- $\quad$ Prepare hostel for re-entry Korean missionary children

Many of Korean missionary children struggle with accommodation at re-entry. This is because the financial condition of missionary parents. Therefore, children face difficulties when getting settled in Korea, and especially finding a suitable accommodation. Beside the financial reason, they also need to get intensive care at the early stage of re-entry. Regarding this, they need accommodation and specific care by adults. There are few hostels ${ }^{12}$ that offer accommodation to re-entry missionary children, but they are not enough for everyone. For this reason, some of the churches and mission agencies in Korea have concerned to establish more hostels for Korean young adult missionary children (Jung 2008.8.13).

- $\quad$ Providing mentoring and care system

In general, missionary children have good understand each other and like to build a close relationship with them. Recently MKNEST ${ }^{13}$ and the Han Dong Global University ${ }^{14}$ have started

12 For the past few years, some Korean churches and mission agencies have established hostels for Korean young adult missionary children who reenter Korea for education.

13 MKNEST is established based on the vision of Helping Korean missionary children through Networking,

Educating, Supporting and Training ministry. (http://www.mknest.org)

14 There are regular meetings for Korean missionary children at Han Dong Global University and in Seoul. 
regular meetings for Korean young adult missionary children to help each other (Park 1999:44). Moreover, they also need a good mentor to share their difficulties and for support. The mentor also needs to understand that part of the mentoring process is helping the children learn the basic survival skills for their home culture (Pollock \& Van Reken 2001:253). Young adult missionary children indeed need guidance about their future such as employment, date and marriage. But it is difficult to find a good mentor and/or counsellor who can understand their specific situation. Yet, providing mentoring and care system is essential for young adult missionary children due to concern their age.

- Providing re-entry program

Attending a transition or re-entry program such as seminar and/or conference is often extremely helpful for many missionary children during re-entry. These programs with other missionary children help them realize they are not alone and are not weird (Pollock \& Van Reken 2001:254). By this missionary children are able to understand their problems in a better way and to accept themselves more.

- Consider a counter plan for university education

Many Korean missionary parents face difficulties to finance their children's education. They need financial support not only for their salaries and work funds, but also for their children's education (Oh 2008:167). Their financial concerns were the main issue among the Korean missionaries in Southern Africa as shown in the results of Oh's research (2008:169). According to his statistics the most important personal problems among Korean missionaries were financial concerns.

Therefore, missionary parents need to make a counter plan for their children's university education while children are young. On the other hand, the churches and the mission agencies need to allow support to be raised for the education of members' children and make a strategy in terms of supporting them. Some mission agencies in Korea have a good support system for the educational expenses of their member's children. For instance, The Paul Mission International ${ }^{15}$ has a good support system for the education of their member's children to help with educational expenses by providing a loan up to university level. A good long-term goal for Korean churches and mission agencies will be to raise funds for an education subsidy to support the education of Korean missionary children.

\section{7.} CONCLUSION

As the history of Korean missionaries abroad lengthens and the number of Korean missionary children increases, Korean missionary parents experience more and more tension about their children's education. Most Korean missionary parents have high expectations for their children's education because the social demands concerning education takes high priority in the thinking of the Korean people (Kim 2004:6). The social atmosphere concerning education in Korea influences Korean missionary parents to have a high fervour for children's education.

Thus, they send their children to MK/International schools for excellent education, but this causes several problems for children (Park 1999:35). Hence, in 1993 KWMA defined the purpose of education for Korean missionary children to be citizens of God, citizens of the world, and citizens of Korea. Since the definition was proclaimed by mission agencies and missionaries in Korea, they have tried to help Korean missionary children to establish these identities. According to KWMA, it is very important that Korean missionary children need to understand who they are (Park 1999:92). With this knowledge they may have the power to adjust to Korea and other countries (Park 1992:93). Considering this, the mission agencies and missionaries in Korea stimulate Korean missionary children to have university education in Korea. Also since Korea

15 The Paul Mission International: www.bauri.org 
expended special admission allowances in 1997 to missionary children, many changes have occurred to the university entrance for Korean missionary children. A tendency has arisen that Korean missionary children changed from a Western to a Korean college/university through the special admission allowance (Jae 2002:15).

In fact, many of Korean missionary children are afraid to renter to Korea for college/university education because of its disadvantages and they argue that studying in America and/or in other Western countries have more advantages to develop broader thinking and a globalized perspective, to experience western culture and customs, and to get to know the people. They are critical with shaping their identities as citizens of $\operatorname{God}^{16}$ and citizens of the world ${ }^{17}$ is value rather than just shaping identity as citizens of Korea (KWMA also emphasized on this fact). Bosch (1993:457) asserts, "the church is the Body of Christ that can only be one". Thus, the church is a kind of "universal hermeneutical community, in which Christians and theologians from different lands check one another's cultural biases" (Hiebert 1985b:16 in Bosch 1993:457). Regarding this, the importance of shaping identity for missionary children is to be citizens of God beyond their identity of their home country, in order to understand diversity in terms of different culture and race.

In general, many missionary children often feel they are "citizens of the world" (Eldse \& Sichel 2004:12), and "feeling at home anywhere" (2004:12) is enough to comfort them. Often the missionary children live with a sense of being "in the middle" (Bowers 1998:49) between home and host countries. They are touched by both and identify with both, yet without a sense of being owned or owning either one. Lim (2004:12) insists that growing up globally, they often enjoy an expanded worldview, but may lack a particular national identity. The identity of missionary children is a combination of all the cultural influences they make their own.

Therefore, it is not obligatory for Korean missionary children to enter Korea for their university education. There should be more opportunities to experience Korean society and culture in the future. On the other hand, some missionary children prefer to go to college/university on the mission field, to stay with their parents.

Up until now, there are only few examples of Korean missionary children who have entered universities in Korea. There is another problem that a large number of Korean people criticize the special admission allowance. They feel this to be preferential treatment. The system of special admission allowance for university entrance has recently been complicated and this system may be more stringent in future. This new attitude towards the special admission allowance for university entrance will influence Korean missionary children in future. Hence, it is important that personal character and preference of college/university options must be seriously considered, as they see the idea of 'one-size-fits' is not appropriate for all. Korean missionary parents and mission agencies need to be open minded instead of persisting in preconceived ideas concerning university education. Alternative options need to be offered to Korean missionary children for their university education.

\section{WORKS CONSULTED}

Back, I S 2007. Missionary children, their university education and the future. MKJOURNAL, 26(1). Bosch, D J 1993. Transforming mission: paradigm shifts in theology of mission. New York: Oribs Books. Bowers, J M 1998. Raising resilient MKs: resources for caregivers, parents, and teachers. Colorado Springs: Association of Christian Schools International (ACSI).

Cha, $\mathrm{H}$ 2007. Educational issues and plans for Korean missionary children. Journal of The Presbyterian Church of Korea, [online]. Available at:http://www.pckworld.net/bbs/tb/php/stratagem/17. [Accessed

161 Peter 2:9

17 Pollock, D J 1998. 'Being a third-culture kid: a TCK profile' [in] Bowers, J M, Raising resilient MKs. 
16 July 2007].

Chan, P 1998. 'Understanding the needs of Asian MKs' [in] Bowers, J M, Raising resilient MKs, Colorado Springs: Association of Christian Schools International (ACSI). 37, 330-342.

Eidse, F \& Sichel, N (ed) 2004. Unrooted childhoods: memoirs of growing up global. Boston. London: Intercultural Press. Nicholas Brealey Publishing.

Hale, J 2003. What about MK education: new alternatives to an old problem. NICS (Network of International Christian Schools), 30, 13-14.

Jae, S O 2002. Concentration of the investigation of education for Korean missionary children. M.Div thesis. Chongshin University in South Korea. http://www.chongshin.ac.kr

Jung, M Y 1999. 'Education for Korean MKs and the future of Korean mission' [in] Park, S N, Korean MK Handbook, Seoul Korea: Korean Oversea Mission Press, 15-51, 86-99.

Jung H K 2008. Weekly Newspaper, The Kidok Shinmun, "Complication of identity is a difficult issue", 13 August, p.20.

Kim, D H 1999. 'Character of MKs and the aim of education for Korean MKs' [in] Park, S N, Korean MK handbook, Seoul Korea: Korean Oversea Mission Press, 55-68.

$\mathrm{Kim}, \mathrm{H} J$ 2004. Analyzing the effects of the high school, equalization policy and the college entrance, system on private tutoring expenditure in Korea. KEDI Journal of Educational Policy. 1(1).

Kim Y S 2007.Weekly Newspaper, The KidokShinmun, "Distribution of the Korean missionaries", 8 October, p.20.

Kwon, D H 2006. Living in a yellow submarine: third culture experience of Korean missionary kids at Faith Academy, Asia Culture Forum, 1-24.

Lee, J H 2007. A pioneer of Korean MK school. MKJOURNAL, 13(5).

Lim, D S 2004. Relationship between the Korean church and MK education. Mission Journal, Global Mission Society (GMS) in South Korea, 41(1), 8-15.

Moon, S C 2007. The acts of Koreans: a research report on Korean missionary movement. [online]. Available at:http://krim.org/files/doc. [Accessed 30 Sep 2008].

$\mathrm{Ng}, \mathrm{B}$ 2007. Language issues in MK education. This paper was presented at a workshop of the SIM IMKEC (International MK Education Consultation), 1-9 November 2007, Chiang mai, Thailand.

Nho C R 2002. A study on university adjustment among returnees of overseas-experienced students; focusing on relationships among stress, perception of university environment, life satisfaction, and self-esteem, and service needs. Mental Health and Social Work. 13(87-120).

Oh, $\mathrm{K} \mathrm{H}$ 2008. Korean missionaries in Southern Africa: a discussion and evaluation of Korean missionary activity in Southern Africa, 1980-2006. PhD thesis, University of Pretoria in South Africa. http://www. up.ac.za

Park, J H 2002. A plan for the realities of education for Korean missionary children, M.Div thesis. Kyeyak University in South Korea. http://www.kyeyak.ac.kr

Park, S N 1999. Korean MK handbook. Seoul Korea: Korean Oversea Mission Press.

Park, S N 2007. Reentry education. MKJOURNAL. [online]. Available at:http://www.mknest.org [Accessed 20 May 2009].

Pollock, D C 1998. 'Being a third-culture kid: a TCK profile' [in] Bowers, J M, Raising resilient MKs, Colorado Springs: Association of Christian Schools International (ACSI), 45-53.

Pollock, D C \& Van Reken, R E 2001. The third culture kids: the experience of growing up among worlds. Boston. London: Nicholas Brealey. 


\section{KEY WORDS}

Korean missionary children

Mission field

Educational issues

Identity issues

University education

\section{TREFWOORDE}

Universiteitsopleiding

Onderwys

Identiteit

Sendingveld

Kinders van Koreaanse sendelinge

Contact details:

Prof. JC Muller

Department of Practical Theology

University of Pretoria

Tel. 0124202700

E-mail: Julian.muller@up.ac.za

Dr. Hee kyung Young

PO Box 76234

Lynnwoodrif

Pretoria

0040

Tel. 0129918094

0822534084

E-mail: khohsim@gmail.com 